\title{
Application of Soga Tingi (Ceriops Tagal) as an alternative eco-friendly textile color
}

\author{
A. Hendrawan \\ Telkom University, Bandung, Indonesia \\ S. Mohamad \\ Universiti Sains Malaysia, Pulau Penang, Malaysia \\ W. Listianingrum \\ Telkom University, Bandung, Indonesia
}

\begin{abstract}
The negative impact of synthetic dyes caused natural dyes to be widely applied as an alternative method of textile coloring in Indonesia. This matter was supported by the Indonesian government and society, especially the fashion industry, as utilizing natural ingredients is a method for eco-friendly textile coloring. One of the materials that can be used as a natural dye is soga tingi. Soga tingi contains a natural pigment named tannin that could be produced as a brown coloring extract. This extract can be produced by boiling the bark of the old soga tree, in addition to exploring the potency of soga tingi as natural dyes using the extraction method. This research aims to find the color variation of soga tingi extract using three kinds of mordant: alum, iron, and whiting. The extract can be applied in the textile product as eco-friendly natural dyes.
\end{abstract}

Keywords: Natural Dye, Soga Tingi, Textile Dyes, Eco-friendly, Extraction, Mordant

\section{INTRODUCTION}

Natural dyes are alternative textile dyes that are non-toxic, can be renewable, are easily degraded, and environmentally friendly (Pujilestari 2015). Using natural materials as textile dyes could preserve natural resources, improve the community's economy, and add cultural value to its products. Natural dyes have great potential to be developed.

The use of natural dyes in textiles has been widely applied in Indonesia. One of the natural ingredients that can be used as a natural dye is soga tingi. Soga tingi's bark (Ceriops tagal) contains tannins that can produce a reddish-brown color on the fabric. (Jansen et al. in Pujilestari, 2015). This extract is obtained by boiling bark from soga trees with air solvent. Natural coloring agents can be obtained by extracting from various parts of the plant using air solvents at high or low temperatures. (Purnomo in Pujilestari, 2015). Based on the description above, the author sees the potential possessed by high-purity soga plants to be processed and made as natural dyes. This study found color variations produced by soga tingi extract with three types of mordant, namely alum, iron, and whiting using the hot dipping method and six time variations namely 10 minutes, 20 minutes, 30 minutes, 40 minutes, 50 minutes, and 60 minutes.

\section{Data}

\section{Natural dyes}

We can obtain natural coloring agents for textiles from the extraction of various parts of plants such as roots, stems, leaves, bark, flowers, and fruit. Each plant can be a coloring agent and produce distinct colors, depending on the pigment in it. Some plants have pigments that are naturally formed in them. Some also form during heating, storage, or processing. According to Susanto (1973) in Handayani (2015) some plants that can be used as natural dyes includeL 
- Nila Leaf (Indigofera Sp.)

- Jelawe Fruit (Terminalia belerica)

- Soga tingi bark (Ceriops candolleana arn)

- Secang (Caesalpinia sappan L)

- Tegeran Wood (Cudraina javanensis)

- Turmeric (Curcuma)

- Tea (Tea)

- Noni Root (Morinda citrifelia)

- Soga jambal's bark (Pelthophorum ferruginum)

- Kesumba (Bixa orelana)

- Guava Leaf (Psidium guajava).

\begin{abstract}
Soga plants
Soga plants (Peltophorum pterocarpum) are a group of plants used as batik dyes whose wood ranges from reddish-brown to black. They can be classified as legumes (Fabaceae or Leguminosae) which spread in Asia. There are three types of soga trees that are usually used including Jambal (Peltophorum pterocarpum), Tegeran (Cudraina javanensis), and Tingi (Ceriops Tagal). Jambal produces a reddish-brown color from the woody trunk, and when the flowers blossom, this tree will be lively with bunches of flowers that appear in unison; that's why this plant is called a yellow flame three or yellow flamboyant. Tegeran is a thorny shrub tree that is used as a maker of yellow on fabric. This tree is spread in Java, Kalimantan, and Sulawesi, and when used as a natural coloring agent veteran or yellow wood needs to be extracted and given fixation or reinforcing material. Tingi is a clump of shrubs with compound leaves clustered at the ends of the branches. This plant at a glance is similar to mangrove plants but smaller. Tingi bark is used as a producer of a dark brownish-red in textiles (Musman and Arini (2011) in Prasetya 2018). Tingi bark used as a dye is old bark because young tingi bark has an inferior quality with low tannin content (Jansen et al. (2005) in Handayani, 2015).
\end{abstract}

\title{
2 METHOD
}

This study uses an experimental method in the form of extraction of soga bark to become a coloring agent. The material needed is $1 \mathrm{~kg}$ of tall wood and $2 \mathrm{~L}$ of water which is then boiled for $1 \mathrm{hr}$, and the tools necessary are pans, stoves, scales, tongs, measuring cups, used cloth, and bottles. The extraction process begins by boiling high wood with a water solvent for 1 hour until the water volume is reduced by half. Then cool the extract before filtering it using a used cloth. The purpose of this filtering is to separate the extract from the dirt in the form of small pieces of wood and powder. Finally, the extract is put into a bottle and stored in the refrigerator where the extract can last for 14 days.

\section{RESULTS \& DISCUSSION}

The dyeing process is carried out on a baby canvas fabric $10 \mathrm{~cm} \mathrm{x} 10 \mathrm{~cm}$ in size to get color variations from the three types of mordants used. Immersion is carried out with six time variations: 10 minutes, 20 minutes, 30 minutes, 40 minutes, 50 minutes, and 60 minutes. The results of dyeing using soga tingi extract are shown in Table 1.

Table 1. Dyeing exploration with whiting.

\begin{tabular}{|l|l|l|l|l|l|l|}
\hline \multicolumn{7}{|c|}{ Mordan Akhir Kapur } \\
\hline Waktu & 10 Menit & 20 Menit & 30 Menit & 40 Menit & 50 Menit & 60 Menit \\
\hline Hasil & & & & & & \\
& & & & & & \\
\hline
\end{tabular}


Dyeing results in 10 minutes produce a peach color (pale pink with a slight mixture of orange). Dyeing results for 20-30 minutes produce a dark peach color with a less significant color difference. After 40-60 minutes, dyeing results produce orange with a mix of a little pastel pink.

Table 2. Dyeing exploration with whiting + alum.

\begin{tabular}{|c|c|c|c|c|c|c|}
\hline \multicolumn{7}{|c|}{ Mordan Akhir Kapur + Tawas } \\
\hline Waktu & 10 Menit & 20 Menit & 30 Menit & 40 Menit & 50 Menit & 60 Menit \\
\hline Hasil & & & & & & \\
& & & & & & \\
\hline
\end{tabular}

The results of dyeing with whiting fixers and alum produce a dark peach color to brick red. The results of dyeing in 10-20 minutes tend to be the same, as well as color dyeing for 30-50 minutes. In comparison, the 60-minute dyeing results produce a brick red color.

Table 3. Dyeing exploration with alum.

\begin{tabular}{|c|c|c|c|c|c|c|}
\hline \multicolumn{7}{|c|}{ Mordan Akhir Tawas } \\
\hline Waktu & 10 Menit & 20 Menit & 30 Menit & 40 Menit & 50 Menit & 60 Menit \\
\hline Hasil & & & & & & \\
& & & & & & \\
\hline
\end{tabular}

The results of the dyeing of 10-30 minutes produce a light brick red color. For dyeing results after40-50 minutes, the resulting color is darker than the dyeing time of 10-30 minutes, but the colors are not mixed evenly, leaving an impression of being faded. As for the 60 -minute dyeing result, the resulting color is more balanced.

Table 4. Dyeing exploration with alum + iron.

\begin{tabular}{|c|c|c|c|c|c|c|}
\hline \multicolumn{7}{|c|}{ Mordan Akhir Tawas + Tunjung } \\
\hline Waktu & 10 Menit & 20 Menit & 30 Menit & 40 Menit & 50 Menit & 60 Menit \\
\hline Hasil & & & & & & \\
& & & & & & \\
\hline
\end{tabular}

The results of dyeing using alum fixation + iron produce a brown wood color. For a result of 10-40 minutes, the color produced tends to be the same as a barely noticeable comparison. As for the results of 50-60 minutes, the color produced is dark brown wood.

Table 5. Dyeing exploration with iron.

\begin{tabular}{|c|c|c|c|c|c|c|}
\hline \multicolumn{7}{|c|}{ Mordan Akhir Tunjung } \\
\hline Waktu & 10 Menit & 20 Menit & 30 Menit & 40 Menit & 50 Menit & 60 Menit \\
\hline Hasil & & & & & & \\
& & & & & & \\
\hline
\end{tabular}

The color results from the exploration of dyeing by using a fixator tend to be the same as a slight change at any time. However, 60 minutes of dyeing is different as it results in a blackish-brown color.

Table 6. Dyeing exploration with iron + whiting.

\begin{tabular}{|c|c|c|c|c|c|c|}
\hline \multicolumn{7}{|c|}{ Mordan Akhir Tunjung + Kapur } \\
\hline Waktu & 10 Menit & 20 Menit & 30 Menit & 40 Menit & 50 Menit & 60 Menit \\
\hline Hasil & & & & & & \\
& & & & & & \\
\hline
\end{tabular}


The color produced from exploration with a time of 10-20 minutes produces a light brick red. Dyeing results after 30-40 minutes produce brown with a mixture of brick red and dyeing results for 50-60 minutes produce a dark brown color.

Table 7. Dyeing exploration with iron + whiting + alum.

\begin{tabular}{|c|c|c|c|c|c|c|}
\hline \multicolumn{7}{|c|}{ Mordan Akhir Tunjung + Kapur } \\
\hline Waktu & 10 Menit & 20 Menit & 30 Menit & 40 Menit & 50 Menit & 60 Menit \\
\hline Hasil & & & & & & \\
& & & & & & \\
\hline
\end{tabular}

The immersion results by combining the three mordants, iron + whiting + alum, produce a color that is almost the same as exploration using alum + iron fixator. The results of the 10-20 minutes color display brown with a mixture of slightly red brick, while for the results of 30-50 minutes produce a wood brown color. For 60 minutes, dyeing results produce colors such as the color of teak wood.

\section{CONCLUSION}

We can use most plants as coloring agents. This is because the pigment content in them is like tannins, flavonoids, carotene, and anthocyanin which can produce color. The parts of plants that can be extracted as natural dyes include roots, stems, bark, leaves, flowers, and fruit. The extraction method can get natural coloring agents using a water solvent. We can apply the extraction results as textile dyes by hot or cold dyeing methods. Immersion with variations in time and mordant can produce distinct colors. The results of the experiments showed that dyeing for a short time produces a light/pale color while dyeing for a long time can produce dark colors.

\section{REFERENCES}

Aini, R. (2017). Identifikasi Keanekaragaman Pohon Mangrove di Kawasan Wisata Hutan mangrove Teluk Benoa Bali sebagai Dasar Pembuatan Sumber Belajar Biologi. Universitas Muhammadiyah Malang; Vol. 2.

Alamsyah. (2018). Kerajinan Batik dan Pewarnaan Alami. Endogami: Jurnal Ilmiah Kajian Antropologi, 1(2), 136. https://doi.org/10.14710/endogami.1.2.136-148

Farida. (2016). Pengaruh Variasi Bahan Pra Mordant pada Pewarnaan Batik Menggunakan Akar Mengkudu (Morinda citrifolia). Dinamika Kerajinan Dan Batik: Majalah Ilmiah, 32(1), 1. https://doi.org/10.22322/dkb.v32i1.1164

Haffida, A. A. N. (2017). Ektraksi Zat Tanin Dari Bahan Alami Dengan Metode Steam Extraction. Ektraksi Zat Tanin Dari Bahan Alami Dengan Metode Steam Extraction. Retrieved from http://repository.its.ac.id/47639/7/2314030091-2314030112-Non-Degree.pdf

Handayani, P. (2015). Jurnal Bahan Alam Terbarukan. Jurnal Bahan Alam Terbarukan, 4(1), 14-20. https://doi.org/10.15294/jbat.v4i1.3769

Koswara, S. (2009). Pewarna Alami: Produksi dan Pengolahannya. Retrieved from http://tekpan.unimus. ac.id/wp-content/uploads/2013/07/PEWARNAALAMI.pdf

Neraca. (2015). Kemenperin: Kemenperin Gencar Kembangkan Pewarna Alami. Retrieved February 17, 2020, from kementrian perindustrian website: https://kemenperin.go.id/artikel/13256/Kemenperin-GencarKembangkan-Pewarna-Alami

Prasetya, G. (2018). Batik Warna Alam Soga di Home Industry Louby Batik Banyuripan, Bayat, Klaten, Vol. 10.

Pujilestari, T. (2015). Review?: Sumber dan Pemanfaatan Zat Warna Alam untuk Keperluan Industri (Review?: Source and Utilization of Natural Dyes for Industrial Use). Dinamika Kerajinan Dan Batik.

Sulistiami and Fatonah, N. (2013). Penggunaan Penguat Jenis Mordant dan Daun Jambu terhadap Hasil Pewarnaan Teknik Ikat Celup pada Kain Katun. Jurnal Buana Pendidikan, 9(13). 